\title{
Linking Motivation to Employees' Performance: the Mediation of Commitment and Moderation of Delegation Authority
}

\author{
Eric Irakoze ${ }^{1} \&$ Kashosi Gad David ${ }^{2}$ \\ ${ }^{1}$ Ph.D. Student, School of Insurance and Economics, University of International Business and Economics, China \\ ${ }^{2}$ Ph.D. Student, Donglink School of Economics and Management, University of Science and Technology, China \\ Correspondence: Eric Irakoze, Ph.D. Student, School of Insurance and Economics, University of International \\ Business and Economics, China.
}

\author{
Received: May 27, 2019 \\ Accepted: July 19, 2019 \\ Online Published: August 26, 2019 \\ doi:10.5539/ibr.v12n9p13 \\ URL: https://doi.org/10.5539/ibr.v12n9p13
}

\begin{abstract}
This study explores the roles of commitment and delegation authority respectively as a mediator and moderator to evaluate the impact of motivation on employee performance. A survey conducted with 180 employees as participants at OTB (Burundi Tea Office) from 4 tea factories located at Ijenda, Teza, Tora and Rwegura helped to assess the effect motivation has on employees' performance. The correlation and regression analysis in SPSS was supported to evaluate the hypotheses of this research. The results reveal that there is a positive significance correlation between motivation and performance of employees. The outcomes from regression analysis express that commitment and delegation authority as mediator and moderator respectively have an impact on the relationship between motivation and performance of employees.
\end{abstract}

Keywords: motivation, performance, commitment and delegation authority

\section{Introduction}

In the work environment, employees are seen as the foundation of an organization because they contribute to the formation of the company's reputation and image (Ageeva, Melewar, Foroudi, Dennis \& Jin, 2018; Del-Castillo-Feito, Blanco-González \& González-Vázquez, 2019). Thus, interaction of employees with the organization by maintaining the organization's image pushes the organization to achieve its goals, which proves the performance of its employees. Therefore, the organization should first target its employees, once the organization is competent to identify and recognize its employees' needs, then they will be encouraged to work effectively to accomplish the organization's goals (Paillé, Amara \& Halilem, 2018). The organizational success is determined mostly by the motivation of workers (Lee, Raschke \& Louis, 2016). Additionally, Human resources are essential to the success, efficiency, and performance of an organization (Edmondson \& Harvey, 2018). Motivation is fundamental tool to build an enabling atmosphere where ideal performance is probable, this brings us to the question in what way do we guarantee that the individual motivation is at its topmost inside the institute or workstation (Sarpong, D. and Maclean, 2016).

Every organizations possessed their own set of motivations and individual incentives that push him or her to work better; some can be motivated by recognition whereas others can be motivated using monetary incentives (McInerney, Maehr \& Dowson, 2017). Whatsoever the method of employee motivation, the basic to stimulating that motivation as an employer, is through understanding what type of incentives to make available the employees.

Therefore, employee incentive plans must guarantee employees to feel valued, taken care of and considered meaningful. The ultimate thing about motivation is, it is customized as such agendas are intended to encounter the necessities and requirements of employees (Leischnig, Kasper-Brauer \& Thornton, 2018). Motivation does not only inspire creative performance but also demonstrates to workers just how greatly the organization cares (Todericiu, Şerban \& Dumitraşcu, 2013). Feasibly the most vigorous effect of operative motivation is that improved output or performance. Therefore, if employee motivation can be increased, efficiency will inevitably decrease in alignment (Taris \& Schaufeli, 2014). Hence, employee motivation stimulates workstation harmony and employee performance hence increases. Motivated workers will bring about staff retaining and company loyalty, which in the short term will give birth to growth and improvement of the business (Todericiu et al., 
2013). The above arguments strongly mention how employee's motivation is actually essential for an organization's growth, development and success regardless of the size of the institute. The greatest interest of any institute is to exploit its profits and most are achievable largely by depending on various resources such as human resources in particular.

Motivation in previous studies has been established to be crucial to an organization's performance but yet has remained a challenge (Anders Dysvik, 2011; Chatzopoulou, Vlachvei \& Monovasilis, 2015; Lau \& Roopnarain, 2014; Muslim, Dean \& Cohen, 2016; Syafii, Thoyib, Nimran \& Djumahir, 2015; Webb, Perry \& Fennelly, 2015). However, researchers have revealed that motivation is an essential factor that governs how an organization's employee might execute tasks depending on how they are motivated. Different organizations in different countries adopt various methods of motivating workers to improve their performance, and then various organizations have adopted numerous methods of motivating their employees to perform better by using approaches of other successful organizations across the world but still have not generated good performance levels. This paper is matching the impact of motivation on employee's performance by using delegation of authority as a moderator in a different environment, which linked to diverse culture to easy perceive universal motivation factor as no other research has been investigated on it. This outcome will provide a response with the question and demonstrate how delegation authority can or cannot improve motivational levels of employees hence an effect in performance too.

The purpose of this study is to enrich the existent literature on the concept of motivation in the work environment by considering the delegation of authority within the company as the most effective way for employees to feel the company as their own. Additionally, the study is directing to strive every day to build a favorable working environment so that workers are more authentic, innovative and above all productive. Lack of commitment, high employee absenteeism, low employee motivation and low employee productivity are the challenges this paper seeks to address within the organization. For this reason, the organization must consider the influence of motivation on employee performance in the organization to discover the extent to which employees devote time, skills, knowledge and resources to their work due to their motivation.

This research will be useful to managers to maintain workers' social benefits, creating a supportive work environment, strengthening workers' economic capacity, promoting the reconciliation of public servants' professional responsibilities and encouraging workers' participation in decision-making.

The following parts are; the literature review, the methodology, the results, the conclusion and limitation of this study.

\section{Literature Review}

\subsection{Empirical Study Regarding Motivation, Commitment, and Employee Performance}

Motivation is the process that managers exerting his or her influence on employees' behavior in order to inspire them to advance an assigned task (Alnasrallah, 2016). According to (Mc, Ssekakubo, Lwanga \& Ndiwalana, 2014) motivation is a setting goal directed to a certain behaviors of employee and it is a crucial factor that plays a central role in different manager's tasks. Motivation is defined as a psychological process that directing and orienting behavior to a given purpose. It is described as an internal and external factors that empower and provide energy or effort to an individual in order to remain continuously focused to an organizational goal.

The commencement of motivation raises from unsatisfied need for individual, once this persisted, it may create the short of tension which lead to poor performance of employees. However, employee's performance is about the general belief associated with an individual's behavior in conducting an organization at the successful level (Kombo \& Oloko, 2014). Performance of employee is evaluated according to the strategies, knowledge and effort an employee exercise in order to arrive at the setting goal (Parks, 1995). Performance of employee is influenced by different elements in organization, it affects the effectiveness of employee in carrying out a certain work and lead to a desired organizational goal. It is defined as an indicator way to perform a designed task based on job description within a given time (Iqbal, Ijaz, Latif \& Mushtaq, 2015). Motivation came in as an element to stimulate the performance of employee (Alnasrallah, 2016). Several types of research have been directed to find out further about the relationship between motivation and employee performance. According to (Manzoor Ahmed, 2013) in his research directed in Bahawalpur, Pakistan's biggest city concluded that intrinsic factors: empowerment and recognition are of positive influence on employee motivation. The extra empowerment and recognition workers have in an organization is improved, the more is their motivation to work enriched. He further added that there is a positive relationship between employee motivation and organizational effectiveness. In studies conducted by (Sucksmith, 2011) said that tacit incentives like rewards and recognition reassure personnel to "think smart" and to encourage both value and quantity in realizing objectives. According to 
(Kuranchie-mensah \& Amponsah-tawiah, 2016) argued that the success and endurance of the organizations are determined by how the human resource is handled. Majority of organizations have attained the gigantic growth by fully observing with their business plan through a well-adjusted reward and recognition agenda for employers.

A study directed by (Mochiah \& Osei, 2014) searches the effects motivation has on the job performance of employees in Ghana. The findings indicated that employees who are more motivated in their jobs are more contented with their performance, and less expected to leave the organization, but undesirably affects the performance when the workforces are de-motivated. The research discovered that training and development, the promotion has significance on employee performance, the researcher lastly concludes that motivation has a good effect and impact on the general performance of personnel in Ghana. The influence of motivation on the performance of teaching the staff of polytechnics in Ghana and finished that motivation is intensely and clearly interconnected to performance amidst teaching the staff of polytechnics in Ghana (Lipsey Samuel Appiah Kwapong, 2015). According to(Dar \& Uju, 2013)the study targeted at investigating the motivation on workers' performance at designated firms in Anambra state. This result attained from the study showed a connection between extrinsic motivation and performance of operatives. The research discloses that the extrinsic motivation given to employees has a positive influence on their performance. (Addison, Antwi-Asare, 2015) conducted a research on the impact of motivation on employee performance in the financial sector of Ghana, he sampled 80 respondents using a simple sampling random technique and from his discoveries recommends that leadership opportunities, acknowledgment and employee assessment, meeting employee anticipations and socialization are crucial factors that motivate employees (T.O.Addison, Antwi-Asare E.K, 2015).

NurunNabi's self-administered research on the impact of motivation on performance: a case study of Karmasangsthan bank limited, Bangladesh sampled individuals who were designated and interviewed with a self-administered questionnaire to acquire primary data. The data was analyzed using descriptive statistical analysis methods. The results attained indicated that if staffs are positively motivated, it develops both their effectiveness and efficiency for accomplishing the organization's objectives (Nurun Nabi, 2017). Alnasrallah demonstrates in his study that employee motivation has a positive effect on employee performance. Higher employee motivation increases both productivity and employee retention for an organization. Various methods may be implemented by organizations to intensify employee motivation like training and development, social involvement and leadership (Alnasrallah, 2016). In research conducted by (Stella, 2008) focusing on motivational methods and improving workers performance in Kitgum district in Uganda. She found that employees were not performing well in Kitgum district because salaries and allowances at the district were very insufficient and not capable to meet people's basic needs. Teamwork was not there between managers and assistants which was also hindering good performance. The study, however, showed that intrinsic motivators such as achievement, advancement, responsibility, and recognition were lacking in the district.

According to researcher (Mc et al., 2014)conducted a research on a palm oil project in Uganda where he examined the relationship between employee motivation and organizational performance using a quantitative research design integrated into a qualitative method such as questionnaires, surveys used to gather data. The data were analyzed by factor analysis, correlation and regression analysis, the findings show a positive relationship and indicate that if employees were well motivated through for example fair promotion, admissible salary differences, they would work better towards greater performance.

\section{H1: There is a significant and positive relationship between motivation and employee performance.}

\subsection{The Effect of Commitment as Mediator in the Relationship Between Motivation and Performance}

According to (Peters, Tom, 1982) regards the commitment of employees to organizational principles and beliefs the organizational culture as a crucial factor in the success of a company. Commitment to the organization is positively connected to such anticipated outcomes as motivation (Gharakhani \& Davood, 2012)and attendance (Tumpa Dey, Ashok Kumar, 2014) and is negatively connected to the outcome as absenteeism and turnover (Clegg, 1983). Horton too indicated that organization commitment might lead to less turnover absenteeism, hence growth in organization productivity (Jackson, 2012). Employees with great echelons of organizational commitment deliver a confident and steady workforce (Lamastro, 1999) and hence delivering a competitive advantage to the organization.

In research conducted by (Meyer, J. \& Allen, 1991) in the previous studies of the concept of commitment have demonstrated that employee commitment to the organization has a positive influence on job performance. In the study of (Darulehsan, Muthuveloo \& Rose, 2005) in their study discovered that organizational commitment leads to positive organizational outcomes. (Cistulli, Snyder \& Jacobs, 2012)Studied facts of a positive correlation 
between organizational commitment and job performance, the Low commitment has also been connected to low levels of morale (Chughtai \& Zafar, 2006). Non-committed employees may portray the organization in negative terms to outcasts thereby hindering the organization's capability to hire first-class employees (Irefin \& Mechanic, 2014).

Employee commitment is crucial because extraordinary levels of commitment end up into numerous satisfactory organizational outcomes. It replicates the grade to which employees classify themselves with the organization and is committed to its objectives. (Đorđević, 2004) Specified that the commitment of employees is an essential concern because it may be used to foresee employee's performance, absenteeism, and other conducts. (Darulehsan et al., 2005) opined that the organizational commitment is the subset of employee commitment, which included to work commitment, career commitment and organizational commitment and furthermore supplemented that organizational commitment, can encourage high levels of productivity. According to (Liu, 2018)discovered a positive affiliation between commitment and job performance. Employees that are committed to their particular organization are more expected not only to go on with the organization but are also expected to exercise more efforts on the organization's behalf and cooperate in the direction of its success and therefore are also likely to display better performance than the uncommitted employees.

The committed employee has proved to be more inventive; they are less likely to depart from an organization than individuals who are uncommitted (Irefin \& Mechanic, 2014). (Steers, 1977)Realized that more committed employees desire to dismiss from the organization at low rates. There is the advanced purpose of these workers that are committed to their organization, to go on with the organization and they work harder in fulfilling their tasks that will increase their positive approach towards the organization and that will eventually increase the yield of the organization. This will bring about higher employee performance.

In a study directed by (Irefin \& Mechanic, 2014) inspected the impact of employee commitment (Affective commitment, Continuance commitment, and Normative commitment) on employee job performance with a tester sampling of 153 private and public sector workers of oil and gas in Pakistan. The results discovered a positive association between employee commitment and employees' job performance. Therefore, it appeared that when employees are committed to working they would perform better. (Khan \& Jam, 2010)Further advised managers to pay special attention to antecedents of worker commitment and all the factors that foster employee commitment in order to escalate worker performance and successively create a rise in organizational productivity.

In findings of (Ahmad \& Ahmad, 2010) investigated the interdependency of job satisfaction and work performance, the influence of employee commitment and approach towards work on performance by means of a survey data gathered from 310 employees of 15 advertising agencies of Islamabad (Pakistan). They concluded that employees having better worker commitment accomplish tasks well and employees with a good attitude concerning work are highly contented as compared to employees who are less motivated towards their work. According to (Halim \& Rahayu, 2016)observed that there is a positive correlation between business social responsibility and employee commitment the same as between employee commitment and organizational performance. They for that reason concluded that organizations could upsurge their performance through employees' commitment by participating in community activities since such activities also comprise of the welfare of employees and their families.

H2: Commitment has a mediating effect on the relationship between motivation and performance.

\subsection{Effect of Delegation of Authority as a Moderator in the Connection Between Motivation and Employee Performance}

A delegation of authority makes an employee feel appreciated as part of the organization and want to be operative in carrying out the authority consult with him. Thus, workers might try to defend the authority delegated to them by displaying a positive attitude in the accomplishment of the responsibilities and functions via effective utilization of the available resources in the organization. (Kombo \& Oloko, 2014) opined that delegation of authority improves performance in an organization. In studies of (Al-Jammal, I., Al-Khasawneh, J.A \& Hamadat, 2015)examined the impact of the delegation of authority on employees' performance at great Irbid municipality. They measured employee performance via efficiency, effectiveness, and empowerment. However, the data attained were analyzed via mean, standard deviation, and T-test statistic. Their results showed that efficiency, effectiveness as well as empowerment of employees is statistically significant to a delegation of authority in Irbid municipality.

The study of (Al-Jammal, I., Al-Khasawneh, J.A \& Hamadat, 2015) investigated the relationship between delegation authority process and rate of effectiveness: case study municipality regions of Mashhad. A delegation 
of authority was measured by preparation, appreciation stage, and effectiveness. Correlation analysis was employed as a technique of data analysis. Conclusions of their analysis discovered a significant correlation between the delegation authority process and rate of effectiveness. Thus, appreciation and preparation stage has a greater effect on the rate of effectiveness.

Research conducted at the School of Finance and Banking in Kigali, Rwanda investigated an empirical study on delegation and staff commitment. An Empirical Study a cross-sectional survey design was employed with a sample size of 97. Stratified sampling and random sampling were used as sampling techniques. Descriptive analysis and Pearson Product Moment Correlation Coefficient were the two adopted method of data analysis to analyze the data attained from the respondents. The results specified that staff commitment is positively interrelated with a delegation of authority (Kiiza \& Picho, 2015).

Some researchers discovered that excessive delegation of authority has a negative impact on junior staff performance and job satisfaction. Therefore, a delegation of authority might be an administrative tool of the supervisors to motivate their employees, to enhance self-competence, as well as being a tool for the managers to loaf at work. For example (Salter \& Harris, 2014) asserts that transformational leaders may use delegation of authority to develop their subordinates. However, a laissez-faire leader may delegate to prevent liability for probable failure. A study pointed out that authority is delegated as the employees perform the tasks well; however, this situation can be observed as a greater workload and even as a method of punishment that the managers have the employees perform the tasks belonging to them (Weiss \& Fershtman, 1998).

H3: Delegation of authority has a moderating effect on the relationship between motivation and employee performance.

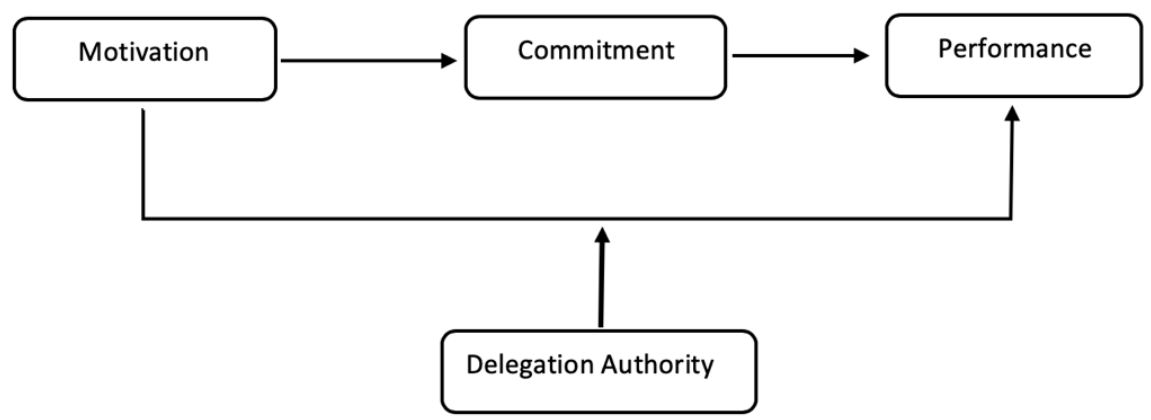

Figure 1. Conceptual Model

\section{Methodology}

In this party, a general view of the methodology is provided. As for this particular study, it focused on data collection methods, sampling techniques, population, and data analysis methods.

Sample and Procedure. The respondents come from Burundi Tea Company, a public company that work in collaboration with 60000 tea formers. A questionnaire was distributed to 180 selected randomly employees using survey monkey software, resulting in 168 responses which gives a response rate of 93 percent, by sending the survey throughout company's e mail, the participants were assured that their feedback would be treated confidentially, in order to avoid the distortion of response that could occur. Of the respondents, 64 were women and 104 men. Their average working experience was between 4 and 9years, and 60 percent of the respondents were of the age between 25 and 34 . This showed that from the chosen sample, a large number of the employees were young and the employees above the age 50 were few.

Measures. All items are measured on a 5-point Likert response scale ordered from $1=$ (strongly disagree) to $5=$ (strongly agree) and are arranged operationally in one way in order to respond the research question and also had been validated in prior studies. The items used are found in Appendix A. Motivation was evaluated by 24 items validated by (Bao \& Nizam, 2015; Nyambegera \& Gicheru, 2016), organization commitment was assessed by 19 items validated by (Irefin \& Mechanic, 2014; Tolentino \& Ng Lungsod Ng Maynila, 2013), delegation authority was measured by 16 items validated by (Al-Jammal, I., Al-Khasawneh, J.A \& Hamadat, 2015), employees' performance was assessed by 15 items validated by (Gohari, Ahmadloo, Boroujeni \& Hosseinipour, 2013). 
Nevertheless, items related to the performance were addressed more to the cadres of the company because the researcher suspected them to be the company's information holders of employees.

Validity and Reliability of Data. The researcher adopted content validity to prove validity of the questionnaire by finding evidence constructed on the content which included assessing if the items represented the construct of what the research is trying to measure, if any essential content parts or themes have been excluded, and lastly if there are any unrelated items included that might be out of the construct. Reliability of the questionnaire was measured using internal consistency reliability, which focused on the items being used to measure the construct. The Cronbach's coefficient alpha was used to measure the reliability of the items which in overall was. 870

\begin{tabular}{ccc}
\hline Cronbach's Alpha & Cronbach's Alpha Based on Standardized Items & Number of Items \\
\hline 0.867 & 0.881 & 74 \\
\hline
\end{tabular}

The Cronbach's alpha value 0.867 and the Cronbach's based on the standardized item alpha value is 0.881 , the two coefficients are between $0.85-0.9$ which shows that the internal consistency of the scale is high, so the reliability is strong.

\begin{tabular}{|c|c|c|c|}
\hline Variables & Cronbach's & Alpha & Number of Items \\
\hline Motivation & 0.703 & & 24 \\
\hline Organizational commitment & 0.789 & & 19 \\
\hline Delegation of Authority & 0.876 & & 16 \\
\hline Performance & 0.721 & & 15 \\
\hline
\end{tabular}

The validity condition state that the Cronbach's alpha of each variable is greater than 0.6 which indicates that the total reliability of each variable is high and has passed the test.

Analysis. We supported by Pearson correlation analysis and hierarchical moderated regression using SPSS Software to test the hypothesizes of this study (Cohen, 1990).

\section{Results}

Table 4 1. Pearson Correlation between variable

\begin{tabular}{|c|c|c|c|c|c|c|}
\hline & Mean & Std. Deviation & 1 & 2 & 3 & 4 \\
\hline 1. $\quad$ Motivation & 84.47 & 9.306 & 1 & & & \\
\hline 2. Organizational Commitment & 64.73 & 7.128 & $.204^{* *}$ & 1 & & \\
\hline 3. Delegation of Authority & 59.57 & 8.911 & $.571^{* * *}$ & .045 & 1 & \\
\hline Performance & 55.71 & 6.716 & $.537^{* *}$ & $.408^{* *}$ & $.502^{* *}$ & 1 \\
\hline
\end{tabular}

**. Correlation is significant at the 0.01 level (2-tailed). $\mathrm{N}=168$

The correlation analysis shows that the correlation between motivation, organizational commitment, and delegation of authority is positively significant with the intensity of the dependent variable performance. There is a significant positive correlation between employee motivation and performance $(r=0.537, \mathrm{p}<0.000)$. The correlation coefficient between employee motivation and performance is 0.537 indicating a strong relationship meaning as employee motivation grows, so does a performance at the same time. The results from the Pearson correlation coefficient support or show evidence of hypothesis (H1) which stated that there is a significant positive relationship between employee motivation and performance.

Regression analysis for mediating effect of variables: Regression analysis was adopted to measure the relationship between a dependent variable and multiple independent variables and in this case, we shall test dependent variable performance with motivation and organizational commitment to assert their effect on one another. 
Table 4 2. Standardized betas and degree of significance of variables from the regression analysis.

\begin{tabular}{lccc}
\hline Relations & $\beta$ & $\mathrm{t}$ & $\mathrm{p}$ \\
\hline Motivation $\rightarrow$ Performance & 0.537 & 8.208 & 0.000 \\
Motivation $\rightarrow$ Organizational Commitment & 0.204 & 2.689 & 0.008 \\
Organizational Commitment $\rightarrow$ Performance & 0.408 & 5.766 & 0.000 \\
Motivation\& Organizational Commitment $\rightarrow$ Performance & 0.474 & 7.575 & 0.000 \\
Motivation $\rightarrow$ Organizational Commitment $\rightarrow$ Performance & 0.312 & 4.986 & 0.000 \\
Note $\mathrm{n}=168$ & & & \\
\hline
\end{tabular}

Table 4 3. The results from the hierarchical regression analysis of Commitment

\begin{tabular}{lcccc}
\hline & Model1 & Model2 & Model3 & Model4 \\
\hline Motivation & 0.537 & 0.204 & & 0.474 \\
Performance & & & 0.408 & 0.312 \\
Commitment & & & & \\
Motivation * Commitment & & & \\
Adjusted $R^{2}$ & 0.284 & 0.360 & 0.162 & 0.374 \\
$\Delta R^{2}$ & 0.289 & 0.420 & 0.167 & 0.382 \\
$\mathrm{~F}$ & 67.378 & 7.229 & 33.248 & 50.960 \\
$\Delta F$ & 67.378 & 7.229 & 33.248 & 50.960 \\
\hline
\end{tabular}

$\mathrm{R}^{2}=38.2 \%$ taken as a set, the predicators Organizational commitment and motivation account for $38.2 \%$ of the variance in Performance. In reference to the results, the regression analysis was applied to establish a relationship between independent variable motivation and dependent variable performance, which showed as significant with a $(\beta=0.537, \mathrm{p}<0.000)$. The coefficient shows that employee motivation explains a significant amount of unique variance in Performance. In other words, the amount of variance that employee motivation accounts for, explains in Performance unique to itself is significant. The second step in the regression analysis was to create a relationship between independent variable motivation and dependent variable organizational commitment. This relationship was significant too with a $(\beta=0.204, p<0.008)$, meaning that the more motivated employees are, the more committed they will be to the organization. The third step is to establish a relationship between organizational commitment and dependent variable performance, which had a strong significant relationship of $(\beta=0.408, p<0.000)$, the meaning is an increase in organizational commitment, will also see an increase in performance too. The final step is to establish a relationship between independent variables motivation and organizational commitment and dependent variable performance. This analysis will create a mediating effect where organizational commitment will be a mediator between motivation and performance. With $(\beta=0.474, p<0.000)$ and $(\beta=0.312, \mathrm{p}<0.000)$ showed a strong significance for motivation and organizational commitment respectively with performance as it was statistically found. This supports the hypothesis $(\mathrm{H} 2)$ proving that organizational commitment has a mediating effect on the relationship between motivation and performance.

\section{Regression analysis for moderation effect between the variables}

Table 4 4. Standardized betas and degree of significance from regression analysis

\begin{tabular}{lccc}
\hline Relations & $\beta$ & $\mathrm{t}$ & $\mathrm{P}$ \\
\hline Motivation $\rightarrow$ Performance & 0.54 & 8.423 & 0.000 \\
Delegation Authority (Moderator) & -0.184 & -2.868 & 0.005 \\
\hline
\end{tabular}

The table demonstrates that motivation has a $(\beta=0.540, \mathrm{p}<0.000)$ which is statistically significant to performance and moderator (delegation of authority) had a $(\beta=-0.184, \mathrm{p}<0.005)$ which indicated a negative significance to performance. From the above analysis, hypothesis (H3) is supported implying that delegation of authority does have a moderating effect between employee motivation and performance. This means that when a delegation of authority is high, performance to increases as illustrated in a graph of the figure below. 


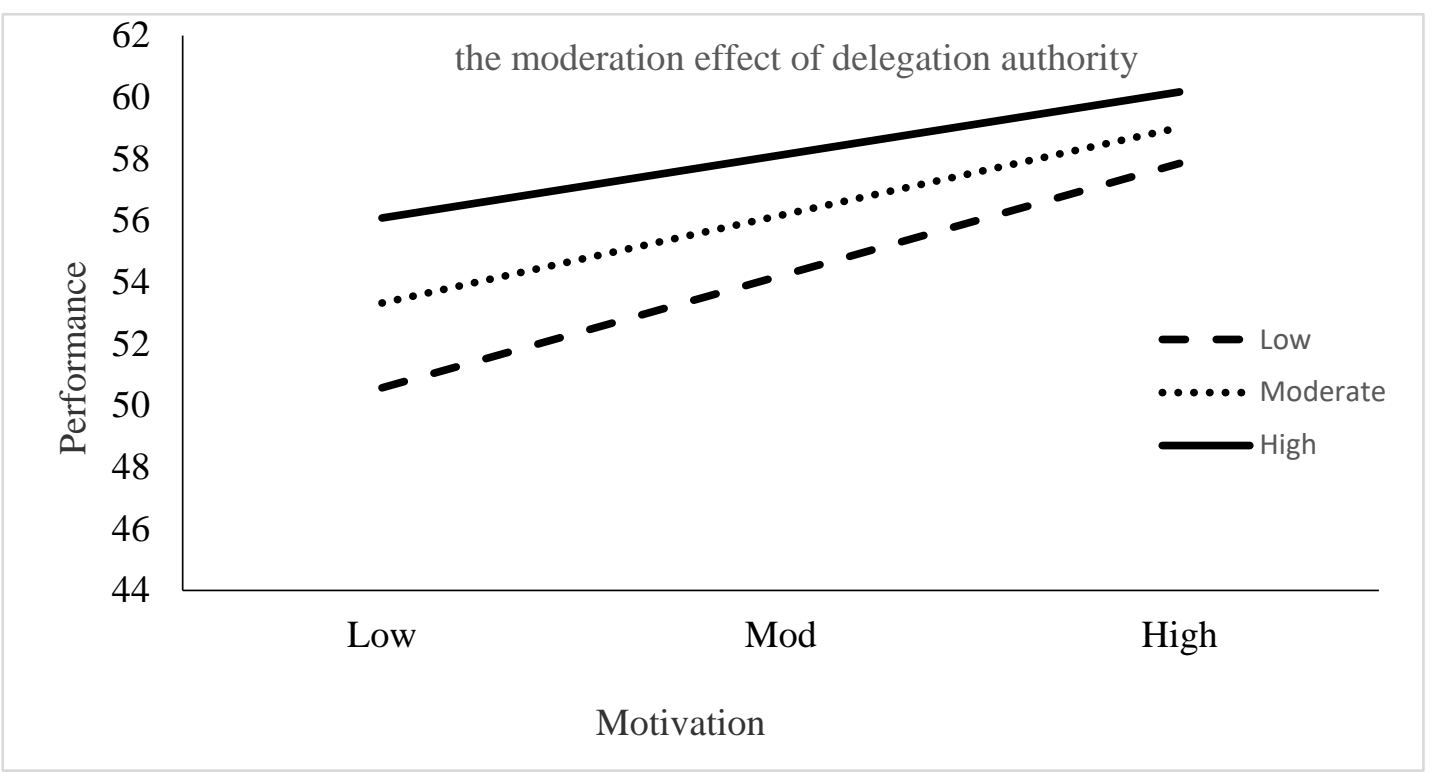

Figure 2. The moderation role of delegation authority in the relationship between motivation and employees' performance

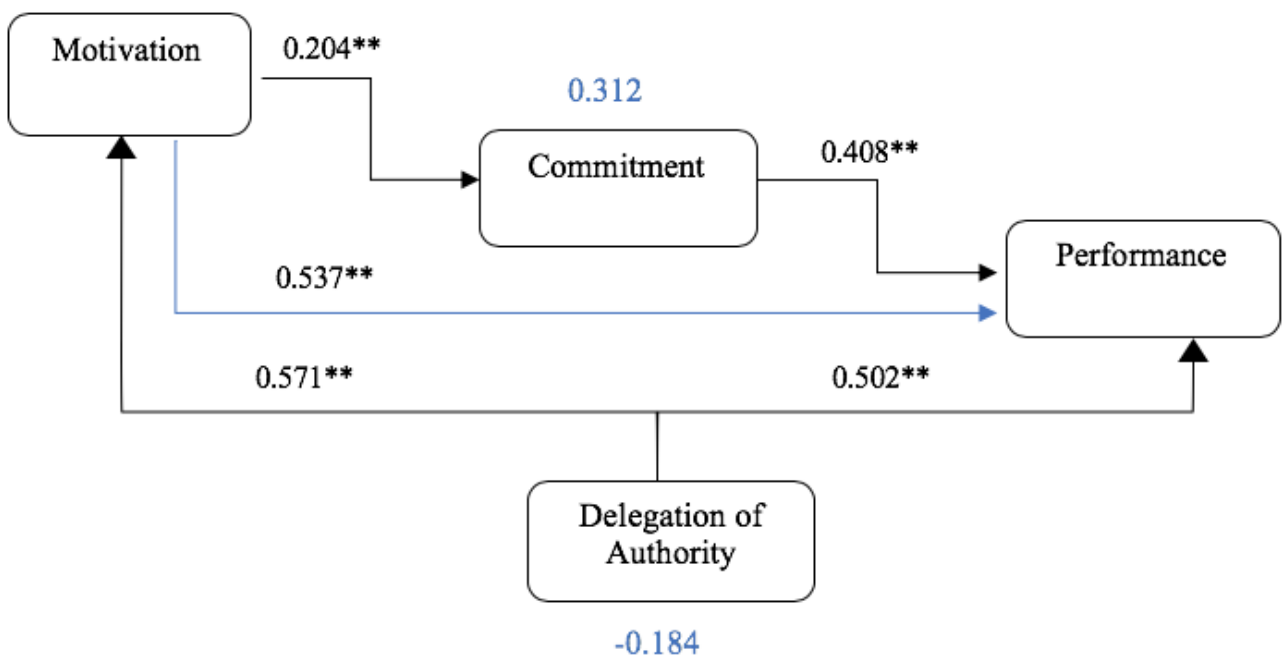

Figure 3. Hypothesized Model with results

\section{Discussion}

This research is conducted in Burundi Tea company, noted that Tea is one of the products that Burundi exports in large quantity and generates income to the country.

From the analysis, the validation of hypothesis (H1) implies that as motivation increases, performance to increases: when an employee is highly motivated it will result in high performance at the organization. Management of Burundi Tea Company is more requested to concentrate and consider on how its employees are motivated because motivation has been proved as an essential tool towards achieving high levels of performance from this study and other previous studies (Clegg, 1983; Dar \& Uju, 2013; Elnaga \& Imran, 2013; Irefin \& Mechanic, 2014; Saari, 2012; Taylor, 2007). The company can put to use both intrinsic and extrinsic motivational packages as earlier studies have suggested too, Burundi Tea Company's employees have been found to be motivated and their performance is influenced to their level of motivation.

Similarly, organizational commitment and motivation had a positive and significant relationship. Thus, the 
findings show the mediating effect of organizational commitment between motivation and performance of the employee. Therefore, organizational commitment is crucial and very important in working place which increases the performance of workers because it is vital for an organization to have complete levels of employee commitment in order to have an exceptional performance on a long term basis (Sutton \& Griffin, 2004). As levels of organizational commitment increase in the company, performance levels of employees ultimately increase too. According to(Khan \& Jam, 2010) research of organization commitment, an employee feels chilling in terms of job environment and this lead to increase organizational commitment which implied high job performance. The results give insights into Burundi Tea Office, the managers are intended to mobilize the employee to be committed in their job in order to increase the performance (Khan \& Jam, 2010). Together organizational commitment and employee motivation lead to better performance of employees. Managers are called to make attention to the commitment of employees by considering their motivation. As Burundi Tea Office is special company for Burundi economical sustainability, its employees are core elements in productivity growth of the company. So, the company has to put policies which foster the capability of employees to remain committed to their job based on their motivation. Stimulation of employee remaining committed drives the company to perform better by increasing its productivity (Mc et al., 2014).

The results indicated that motivation was significant to performance and when it came to the moderating effect, a delegation of authority showed a negative significance in the relationship to performance. Considered the research carried by (Anders Dysvik, 2011) states that intrinsic motivation moderates the linkage of perceived job autonomy and work quality. the results from that study demonstrated that employee with high intrinsic motivation tend to be more responsible in job attributed finally ends up by performing better, in another hand the employee with low intrinsic motivation is less engaged to the job. This explains that at Burundi Tea Company, employees perceive delegation of authority has a significant effect on their levels of performance. For that, employee delegated for being in charge of any level of the company or get any responsibility for others seem to be more motivated and strive to increase the performance of the company. In that case, managers and supervisors should not misuse delegation of authority for their own benefits, they should take it as an advantage to motivate enough employees though attributing them some responsibility by assigning tasks that employees comprehend and are capable to execute well without seeking guidance from them. Supervisors and managers, however, have to entrust their employees to execute certain tasks by delegating more tasks and responsibilities to them that helps to enforce high levels of confidence in employees and a good sense of belonging to the employees with the organization, hence reproducing high-performance levels in the long run.

\section{Implication}

This paper has a big significant implication for the country and managers. Based on the results found for organizational commitment and delegation authority playing their roles of moderation and mediation respectively in the connection between motivation and performance. A country should impose rules and regulation, which favor employee working environmental such as cut personal income tax, provision of insurance, to boost their well-being in order to stimulate the productivity growth, as Burundi Tea Company is a public company. Managers are advised to make employees remaining committed to their tasks and rotating them in commandment position as being a part of delegation authority to perform certain tasks, this will drive them to be intrinsically motivated then will lead the company to the preferred performance.

This study met some limitations, firstly data collection, the sample size was too small regarding the total number of employees. Since we have a small sample size, this study cannot be generalized based on the results gotten. Secondly, this study had a financial problem because we collected data from different tea company located in different provinces, we faced some barriers such as transportation cost, accommodation, and time which was not enough for distribution and collection the questionnaire

We recommend future research with the inclusion of an additional qualitative data and depth information (i.e. from tea plantation field, production, and commercialization areas) for all employees working Burundi Tea Company in order to come up with précised information and capture enough respondents from a different area of the company.

\section{References}

Addison, T. O., \& Antwi-Asare, E. K. Y. (2015). Financial Sector Reforms and Bank Performance in Ghana. (N. The Russell Press Ltd, Ed.). London SW1E5DP: Portland House.

Ageeva, E., Melewar, T. C., Foroudi, P., Dennis, C., \& Jin, Z. (2018). Examining the influence of corporate website favorability on corporate image and corporate reputation: Findings from fsQCA. Journal of Business Research, 89, 287-304. Elsevier. https://doi.org/10.1016/j.jbusres.2018.01.036 
Ahmad, H., \& Ahmad, K. (2010). Relationship between Job Satisfaction, Job Performance Attitude towards Work and Organizational Commitment. European Journal of Social Sciences, 18(2), 257-267.

Al-Jammal, I., Al-Khasawneh, J. A., \& Hamadat, A. M. (2015). Impact of the delegation of Authority and Employee Performance at IRBID municipality. International Journal of Human Resource Studies, 5(3), 61-72. https://doi.org/10.5296/ijhrs.v5i3.8062

Alnasrallah, Y. (2016). Employee Motivation and Performance. International Journal of Scientific \& Engineering Research, 7(1), 788-790.

Anders, D. B. K. (2011). Intrinsic motivation as a moderator on the relationship between perceived job autonomy and work performance. European Journal of Work and Organizational Psychology, 20(3), 367-387. https://doi.org/10.1080/13594321003590630

Bao, C., \& Nizam, D. I. (2015). THE IMPACT OF MOTIVATION ON EMPLOYEE PERFORMANCE IN THE ELECTRONICS INDUSTRY IN CHINA. International Journal of Accounting and Business Management, 3(2), 29-45. Retrieved from http://www.ftms.edu.my/journals/IJABM/Nov2015/29-45.pdf

Chatzopoulou, M., Vlachvei, A., \& Monovasilis, T. (2015). Employee's Motivation and Satisfaction in Light of Economic Recession: Evidence of Grevena Prefecture-Greece. Procedia Economics and Finance, 24, 136-145. https://doi.org/10.1016/S2212-5671(15)00633-4

Chughtai, A. A., \& Zafar, S. (2006). Antecedents and Consequences of Organizational Commitment Among Pakistani University Teachers. Applied H.R.M. Research, 11(1), 39-64.

Cistulli, M. D., Snyder, J. L., \& Jacobs, R. (2012). Affective Organizational Commitment as a Predictor of Military Enlistment Discussion and Recommendation United States of America. Business, Humanities and Technology, 2(3), 27-33.

Clegg, C. W. (1983). (1983). Psychology of employee lateness, absence, and turnover:a methodological critique and an empirical study. Applied Psychology, 68, 88-101. https://doi.org/10.1037/0021-9010.68.1.88

Cohen, J. (1990). Things I Have Learned ( So Far ). American Psychologist, 45(12), 1304-1312. https://doi.org/10.1037/0003-066X.45.12.1304

Dar, B., \& Uju, S. (2013). The Influence of Motivation on Employees ' Performance: A Study of Some Selected Firms in Anambra State. An International Journal of Arts and Humanities, 2(7), 134-151.

Darulehsan, S., Muthuveloo, R., \& Rose, R. C. (2005). Typology of Organisational Commitment. Applied Science, 2(6), 1078-1081. https://doi.org/10.3844/ajassp.2005.1078.1081

Del-Castillo-Feito, C., Blanco-González, A., \& González-Vázquez, E. (2019). The relationship between image and reputation in the Spanish public university. European Research on Management and Business Economics, 25(2), 87-92. Elsevier Doyma. https://doi.org/10.1016/j.iedeen.2019.01.001

Đorđević, B. (2004). EMPLOYEE COMMITMENT IN TIMES OF RADICAL ORGANIZATIONAL CHANGES Biljana Đ or đ evi ć. Economics and Organization, 2, 111-117.

E. Sucksmith1, I. R., \& R. A. H. (2011). re-examining the broader autism phenotype in the 21 st. Neuropsychology Review, 21((4)), 360-389. https://doi.org/10.1007/s11065-011-9183-9

Edmondson, A. C., \& Harvey, J. F. (2018). Cross-boundary teaming for innovation: Integrating research on teams and knowledge in organizations. Human Resource Management Review, 28(4), 347-360. https://doi.org/10.1016/j.hrmr.2017.03.002

Elnaga, A., \& Imran, A. (2013). The Effect of Training on Employee Performance. European Journal of Business and Management, 5(4), 2222-2839.

Gharakhani, J. E., \& Davood. (2012). Organizational Commitment and Job Satisfaction. Science and Technology, 2(2), 85-91.

Gohari, P., Ahmadloo, A., Boroujeni, M. B., \& Hosseinipour, S. J. (2013). The relationship between rewards and employee performance. INTERDISCIPLINARY JOURNAL OF CONTEMPORARY RESEARCH IN BUSINESS . Retrieved from https://journal-archieves34.webs.com/543-570.pdf

Government, L., \& Stella, O. (2008). Motivation and Work Performance: Complexities in Achieving Good Performance Outcomes ; A Study Focusing on Motivation Measures and Improving Workers Performance in Kitgum District, (December), 83.

Halim, L., \& Rahayu, M. (2016). The Effect of Employee's Perceptions on Corporate Social Responsibility 
Activities on Organizational Commitment, Mediated by Organizational Trust. International Journal of Business and Management Invention, 5(4), 43-49.

Iqbal, A., Ijaz, M., Latif, F., \& Mushtaq, H. (2015). Factors Affecting the Employee'S Performance: a Case Study of Banking Sector in Pakistan. European Journal of Business and Social Sciences, 4(8), 309-318.

Irefin, P., \& Mechanic, M. A. (2014). Effect of Employee Commitment on Organizational Performance in Coca Cola Nigeria Limited Maiduguri, Borno State. Humanities and Social Sciences, 19(3), 33-41.

Jackson, S. E. (2012). Managing Human Resources.

Khan, M. R., \& Jam, F. A. (2010). The Impacts of Organizational Commitment on Employee Job Performance. Social Sciences, 15(3), 292-298.

Kiiza, P., \& Picho, E. O. (2015). Delegation and Staff Commitment in the School of Finance and Banking, Kigali , Rwanda. Makerere Journal of Higher Education, 7(June 2002), 3-13.

Kombo, B. W., \& Oloko, M. (2014). Effects of Delegation on Employee Performance in Savings and Credit Cooperative Societies in Kisii County. The International Journal Of Business \& Management, 2(7), 203-215.

Kuranchie-mensah, E. B., \& Amponsah-tawiah, K. (2016). Employee Motivation and Work Performance: A Comparative Study of Mining Companies in Ghana, 9(2), 255-309.

Lamastro, V. (1999). Commitment and Perceived Organizational Support. National Forum of Applied Educational Research, 12(3), 1-13.

Lau, C. M., \& Roopnarain, K. (2014). The effects of nonfinancial and financial measures on employee motivation to participate in target setting. The British Accounting Review, 46(3), 228-247.

Lee, M. T., Raschke, R. L., \& Louis, R. St. (2016). Exploiting organizational culture: Configurations for value through knowledge worker's motivation. Journal of Business Research, 69(11), 5442-5447. Elsevier.

Leischnig, A., Kasper-Brauer, K., \& Thornton, S. C. (2018). Spotlight on customization: An analysis of necessity and sufficiency in services. Journal of Business Research, 89, 385-390.

Lipsey, S. A., Kwapong, E. O., \& Donyina, F. (2015). IN GHANAIAN POLYTECHNICS: THE MODERATING ROLE OF EDUCATION AND. Human Resource Management, 3(6), 30-43.

Liu, R. (2018). The Impact of Job Embeddedness on Employee's Performance - The Regulation Study of Relational Embeddedness. Human Resource and Sustainability Studies, 6, 8-23.

Manzoor, A. (2013). Manzo. National Investment Trust Limited, 3, 20-30.

Mc, J. B., Ssekakubo, J., Lwanga, F., \& Ndiwalana, G. (2014). Employee Motivation , Job Satisfaction and Organizational Performance in Uganda's Oil Sub-sector. Management and Business Studies, 3(7), 315-324.

McInerney, D. M., Maehr, M. L., \& Dowson, M. (2017). Motivation and Culture. Reference Module in Neuroscience and Biobehavioral Psychology.

Meyer, J., \& Allen, N. (1991). A three-component conceptualization of organizational commitment. Human Resources Management Review, 1(1), 81-89.

Mochiah, E. E., \& Osei, R. D. (2014). The impact of conditional cash transfer programmes on household work decisions in Ghana. Economic Research, (September).

Muslim, N. A., Dean, D., \& Cohen, D. (2016). Employee Job Search Motivation Factors: An evidence from Electricity Provider Company in Malaysia. Procedia Economics and Finance, 35, 532-540.

Nabi, N., Al, A., Ahmed, T., \& Rahman, S. (2017). Impact of Motivation on Employee Performances a Case Study of Karmasangsthan Bank Limited Bangladesh Good. Human Resource Management Research, 7(1), 54-64.

Nyambegera, S. M., \& Gicheru, C. N. (2016). Extrinsic and Intrinsic Factors Influencing Employee Motivation: Lessons from AMREF Health Africa in Kenya. International Journal of Business and Social Research, 6(9), 20-31. MIR Center for Socio-Economic Research. Retrieved from https://ideas.repec.org/a/mir/mirbus/v6y2016i9p20-31.html

Paillé, P., Amara, N., \& Halilem, N. (2018). Greening the workplace through social sustainability among co-workers. Journal of Business Research, 89, 305-312. 
Parks, S. (1995). Improving workplace performance: historical and theoretical contexts. Monthly Labor Review.

Peters, T. R. W. (1982). In Search of Excellence: Lessons from America's Best Run Companies. (Harper and.). New York.

Saari, P. (2012). INTRINSIC MOTIVATION Psychological and Neuroscientific Perspectives.

Salter, C. R., \& Harris, M. H. (2014). Ba Leadership Model and Moral Development Interim Associate Dean for Academic Affairs Director of the Masters of Science Leadership Program Director of the Integrity Ambassadors in Business. New York.

Sarpong, D., \& Maclean, M. (2016). Cultivating strategic foresight in practice: A relational perspective. Journal of Business Research, 69, 2812-2820.

Steers, R. M. (1977). Antecedents and outcomes of organizational commitment. Administrative Science Quarterly, 22, 46-56. https://doi.org/10.2307/2391745

Sutton, G., \& Griffin, M. A. (2004). psychological contract violations : A longitudinal study of new professionals. Journal of Occupational and Organizational Psychology, 493-514. https://doi.org/10.1348/0963179042596487

Syafii, L. I., Thoyib, A., Nimran, U., \& Djumahir. (2015). The Role of Corporate Culture and Employee Motivation as a Mediating Variable of Leadership Style Related with the Employee Performance (Studies in Perum Perhutani). Procedia - Social and Behavioral Sciences, 211, 1142-1147. https://doi.org/10.1016/j.sbspro.2015.11.152

Taris, T. W., \& Schaufeli, W. B. (2014). A conceptual and theoretical overview.

Taylor, H. (2007). The effects of interpersonal communication style on task performance and well being.

Todericiu, R., Şerban, A., \& Dumitraşcu, O. (2013). Particularities of Knowledge Worker's Motivation Strategies in Romanian Organizations. Procedia Economics and Finance, 6, 405-413. https://doi.org/10.1016/S2212-5671(13)00155-X

Tolentino, R. C., \& Ng Lungsod Ng Maynila, P. (2013). Organizational Commitment and Job Performance of the Academic and Administrative Personnel. International Journal of Information Technology and Business Management, 29(1). Retrieved from www.jitbm.com

Tumpa, D., \& Ashok, K. Y. L. N. K. (2014). A New Look at the Antecedents and Consequences of Organizational Commitment : A Conceptual Study. Humanities and Social Science, 4(1), 281-287.

Webb, E., Perry, M., \& Fennelly, L. J. (2015). Employee Motivation Theory and Application. Security Supervision and Management (pp. 231-240). Elsevier. https://doi.org/10.1016/B978-0-12-800113-4.00018-3

Weiss, Y., \& Fershtman, C. (1998). Social status and economic performance : A survey. European Economic Review, 42, 801-820. https://doi.org/10.1016/S0014-2921(97)00137-2 


\section{Appendix A: Study Questionnaire}

\section{SECTION I: Background Information}

\section{Please kindly tick where it applies to you}

1. What is your gender?

Male [ ] Female [ ]

2. What is your marital status?

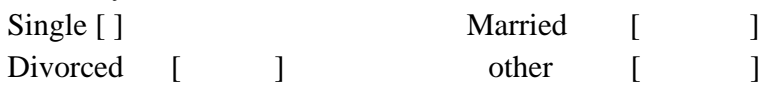

3. What is your age group?

Below $18[$ ] $\quad 18-30[$ ] $31-40[$ ] $\quad 41-50[$ ]

above 50 [ ]

4. Which is your highest level of education?

Certificate [ ] diploma [ ] Graduate [ ] Post graduate [ ]

Other [ ]

5. For how long have you worked the project?

Less than 1 year [ ] 1-4years [ ] 5-9 years [ ] more than 10years [ ]

With Respect To Section Ii, Iii, Iv And V Please Indicate The Level Of Agreement With Each Statement:

Levels Of Agreement

\begin{tabular}{|c|c|c|c|c|}
\hline $\begin{array}{c}\text { STRONGLY } \\
\text { DISAGREE }\end{array}$ & DISAGREE & $\begin{array}{c}\text { NEITHER AGREE NOR } \\
\text { DISAGREE }\end{array}$ & $\begin{array}{c}\text { AGREE } \\
\text { STRONGLY } \\
\text { AGREE }\end{array}$ \\
\hline $\mathbf{( 1 )}$ & $\mathbf{( 2 )}$ & $\mathbf{( 3 )}$ & $\mathbf{( 4 )}$ & $\mathbf{( 5 )}$ \\
\hline
\end{tabular}

\section{Section Ii: Motivation}

\section{Level of Agreement}

$\begin{array}{llllll}1 & 2 & 3 & 4 & 5\end{array}$

\begin{tabular}{|l|l|l|l|l|}
\hline 6. & I am paid a salary that is enough to cater for my basic needs & & & \\
\hline 7. & My company provides me free accommodation/housing & & & \\
\hline 8. & Free meals are provided at the company & & & \\
\hline 9. & Salary payments are prompt & & & \\
\hline 10. & The level at which employees are satisfied with their job can be attributed to their levels of motivation. & & & \\
\hline 11. & $\begin{array}{l}\text { The type of relationship between me and my managers of the organization has an impact on my } \\
\text { motivation. }\end{array}$ & & & \\
\hline 12. & $\begin{array}{l}\text { The degree to which I believe promotion opportunities exist in the organization has an impact on my } \\
\text { motivation. }\end{array}$ & & & \\
\hline 13. & All employees in my company have opportunity for promotion & & & \\
\hline 14. & Am always given paid leave of absence & & & \\
\hline 15. & My company gives me bonuses for extra time worked & & & \\
\hline 16. & My company provides me medical allowance & & \\
\hline
\end{tabular}




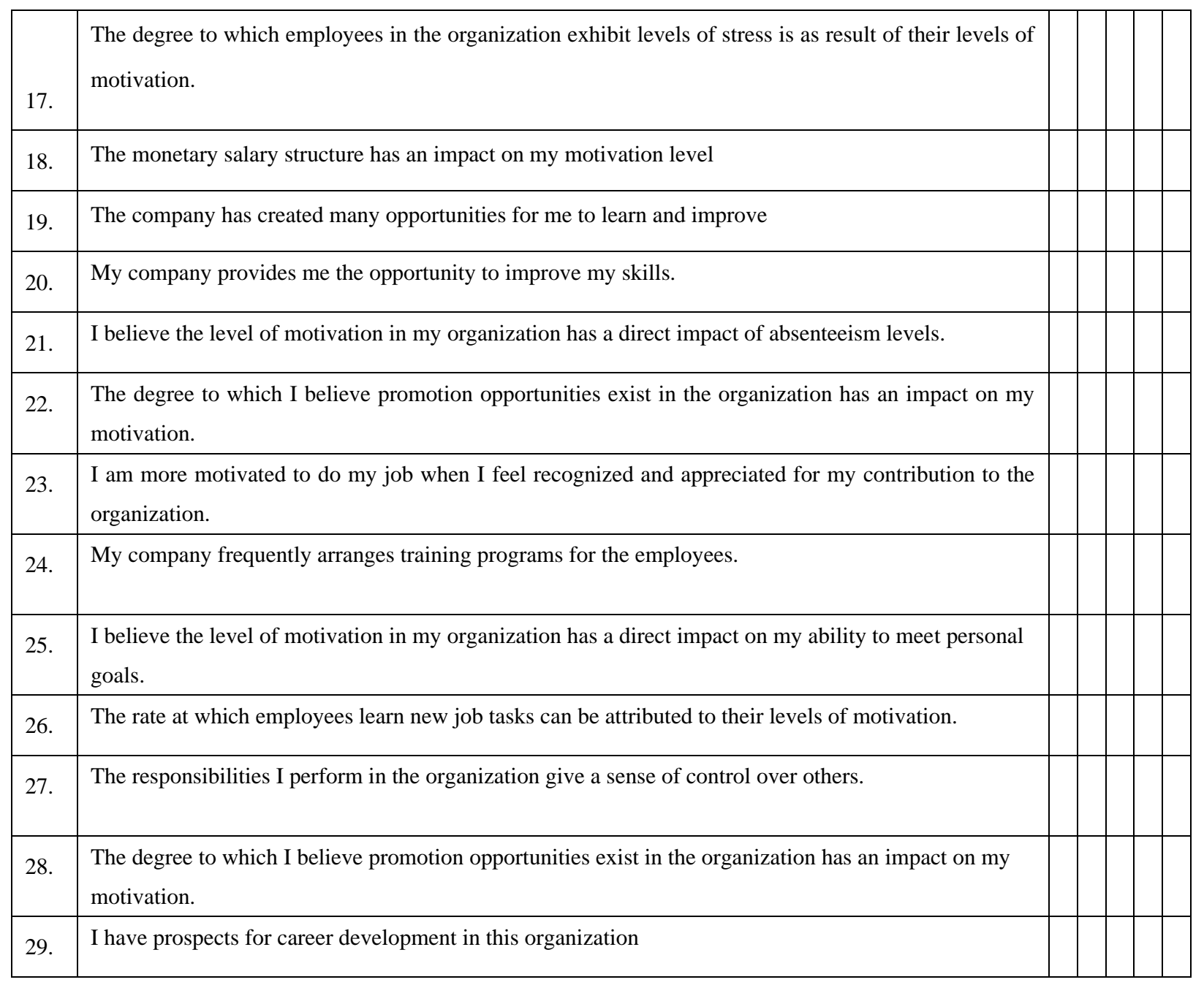

30. What are the other motivational packages for employees in your company?

\section{Section Iii: Organizational Commitment}

\section{Level of Agreement}

$\begin{array}{llllll}1 & 2 & 3 & 4 & 5\end{array}$

\begin{tabular}{|c|c|}
\hline 31. & I feel myself to be part of this organization \\
\hline 32. & I would recommend a close friend to join this company \\
\hline 33. & I feel very little loyalty to this organization \\
\hline 34. & I find that my values and the organization's values very similar. \\
\hline 35. & I understand how my job contributes to the organization's goals and objectives. \\
\hline 36. & I have a good understanding of where the organization is going. \\
\hline 37. & I am willing to put in a great deal of effort to help this organization become successful. \\
\hline 38. & I am not willing to do more than my job description requires just to help the organization. \\
\hline 39. & I would be just as happy working for different organization if the work was similar. \\
\hline 40. & The offer of a little more money with another company would make think of changing jobs \\
\hline
\end{tabular}




\begin{tabular}{|c|c|}
\hline 41. & $\begin{array}{l}\text { I am extremely glad that I chose to work here rather than one of the other jobs I was considering at the } \\
\text { time I joined. }\end{array}$ \\
\hline 42. & There's not much to be gained by staying with this organization indefinitely. \\
\hline 43. & $\begin{array}{l}\text { Often, I find it difficult to agree with the organization's policies on important matters relating to its } \\
\text { employees. }\end{array}$ \\
\hline 44. & I really care about the fate of this organization. \\
\hline 45 . & I think this is a good place to work. \\
\hline 46. & I am proud to be part of my section/ department/ service. \\
\hline 47. & I frequently think of quitting this company \\
\hline 48. & $\begin{array}{l}\text { Even if the company were not doing well financially, I would be reluctant to change to another } \\
\text { company }\end{array}$ \\
\hline 49. & I know that working hard for this organization leading to good performance \\
\hline
\end{tabular}

\section{Section Iv: Delegation of Authority}

\section{Level Of Agreement}

$\begin{array}{llllll}1 & 2 & 3 & 4 & 5\end{array}$

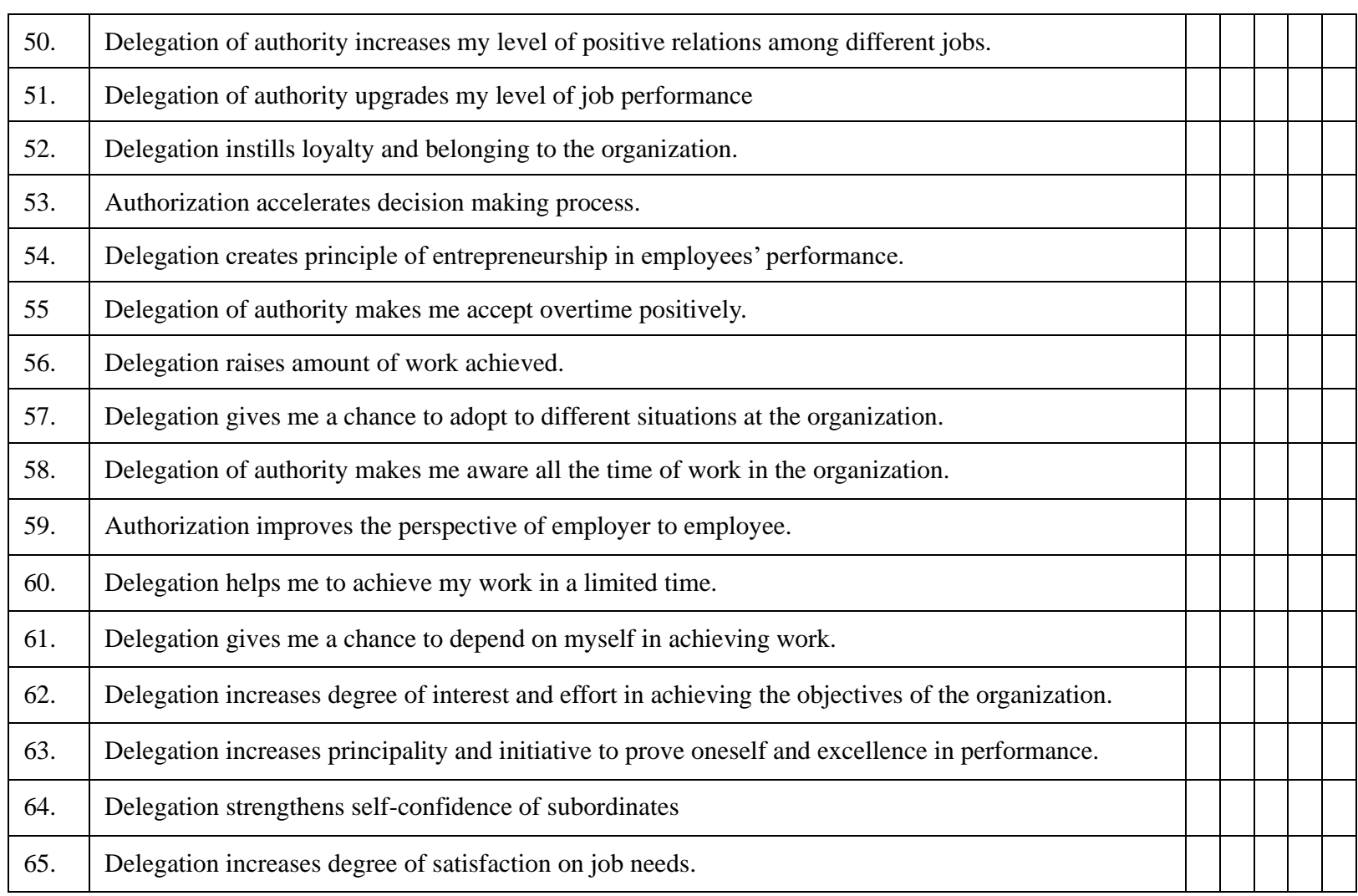

\section{Section V: Performance}

\section{Levels Of Agreement}

1 


\begin{tabular}{|c|l|l|l|l|}
\hline 66. & I feel am doing a good job & & \\
\hline 67. & My superiors appreciate the work I am doing in the organization. & & & \\
\hline 68. & I have a clear understanding of what I need to do to meet my expectations. & & \\
\hline 69. & I have all the support and resources I need from the organization to do my job well. & & \\
\hline 70. & I work collaboratively with my supervisor to set challenging goals. & & & \\
\hline 71. & Still comply with regulations and procedures of the organization in case of difficulty or inconvenient & & & \\
\hline 72. & I use my personal time to improve professional skills & & & \\
\hline 73. & I accept work-related training with a positive attitude & & & \\
\hline 74. & I maintain adequate confidence in the new mission & & & \\
\hline 79. & There is good communication between the supervisor and our team. & & & \\
\hline 80. & I enjoy working with my coworkers. & & & \\
\hline 81. & My supervisor creates a motivating working environment & & & \\
\hline
\end{tabular}

\section{Copyrights}

Copyright for this article is retained by the author(s), with first publication rights granted to the journal.

This is an open-access article distributed under the terms and conditions of the Creative Commons Attribution license (http://creativecommons.org/licenses/by/4.0/). 